\title{
LA INFLUENCIA DEL PROTEVANGELIUM IACOBI EN LA TRADICIÓN HOMILÉTICA MESO-BIZANTINA SOBRE LA MADRE DE DIOS
}

\section{Spyros P. Panagopoulos \\ Universidad Jónica, Grecia}

Resumen: Como la mayoría de los estudiosos están de acuerdo, la devoción a María, la Madre de Jesucristo, comenzó a recibir expresión formal en la mayoría de las fuentes litúrgicas o teológicas hasta aproximadamente el comienzo del siglo IV. Entre otros textos canónicos y apócrifos de finales del siglo II, el Protevangelium es único en su enfoque en la persona de la Virgen María. Basados en el Protevangelium examinaremos las homilías y los sermones meso-bizantinos con ocasión de las fiestas de la Concepción, Nacimiento y Presentacióm de María en el Templo, mientras nos centraremos en los orígenes de las fiestas marianas.

Palabras clave: Protevangelium Iacobi, Theotokos, Homliética, Proclo de Constantinopla, Andrés de Creta, Cosme Vestitor, Juan el Damasceno

THE INFLUENCE OF THE PROTEVANGELIUM IACOBI IN THE MIDDLE-BYZANTINE HOMILETICS ON THE HOLY VIRGIN

Abstract: As most scholars agree, devotion to Mary, the Mother of Jesus Christ, begun to receive formal expression in most liturgical or theological sources until approximately the beginning of the fourth century. Among other canonical and apocryphal texts of the late second century, the Protevangelium is unique in its focus on the person of the Virgin Mary. Based on the Protevangelium we will examine Middle Byzantine homilies and sermons to the Mother of God on the occasion of the feasts of Mary's Conception, Nativity and Presentation into the Temple, while we will focus also on the origins of the Marian feasts.

Keywords: Protevangelium Iacobi, Theotokos, Homlietics, Proclus of Constantinople, Andrew of Crete, Cosmas Vestitor, John of Damascus

Recibido: 9.09.2017 Aceptado: 4.01.2018

Correspondencia: Spyros P. Panagopoulos.

Correo:spyrpan1@gmail.com

Licenciado en Filología griega y en Filosofía en la Universidad de Patras

(Grecia). Investigador de la filología y historia bizantinas. Candidato al doctorado en los Estudios Bizantinos en la Universidad Jónica. 


\section{Introducción ${ }^{1}$}

egún varios eruditos, el Protoevangelio de Santiago (Protevangelium Iacobi) constituye un enigma en la historia para la reverencia de María en la Iglesia Primitiva. ${ }^{2}$ Los estudiosos han aceptado ampliamente la datación del texto a mediados o finales del siglo II, sobre la base de los relatos de Orígenes y Clemente de Alejandría acerca de esto en sus escritos ${ }^{3}$. Además, la hipótesis de que se trata de una obra sintética, que recibió adiciones en los siglos posteriores, fue disputada convincentemente por el editor del Protoevangelio, E. De Strycker. Lo que es más impresionante sobre el texto, que fue la inspiración para el desarollo litúrgico e iconográfico posterior de la fiesta de la infancia de la Virgen María, especialmente en la tradición bizantina y cristiana oriental, es su presencia autónoma durante el período inicial. Como la mayoría de los estudiosos están de acuerdo, el honor a la Virgen María comenzó a recibir una expresión formal en las fuentes más litúrgicas y teológicas hasta aproximadamente el comienzo del siglo IV $^{4}$. El culto a la Santísima Virgen alcanzó su apogeo después del establecimiento de la Virgen María como "Theotokos" en el Concilio de Éfeso en el año 431

1 Nota: Este artículo ha sido presentado como una comunicación de conferencia en el simposio internacional sobre la literatura apócrifa cristiana, que tuvo lugar en Salónica, 26-29 junio 2014.

2 Una edición crítica puede encontrarse bajo E. De Strycker, La forme la plus ancienne du Protévangile de Jacques (Subsidia Hagiographica 33), Bruselas 1961. Una traducción al inglés existe en J.K. Elliott, The Apocryphal New Testament. A Collection of Apocryphal Christian Literature in an English Translation Based on M.R. James, Oxford, 1993; edición revisada 2004.

3 Comentario sobre el evangelio de Mateo, 10, 17 en E. Klostermann-E. Benz, (eds.), Die Griechischen Christlichen Schriftsteller 40/1, Leipzig, 1935, pp. 21-22; Clemente de Alejandría, Stromata, 7.16 .93 en O. Stählin (ed.), Die Griechischen Christlichen Schriftsteller 52 (17) /2, Leipzig, 1906, p. 661.

4 Véase M. Cunningham, "The use of the Protoevangelion of James in 8thcentury homilies on the Mother of God" en L. Brubaker and M. Cunningham (eds.), The Cult of the Mother of God in Byzantium. Texts and Images, Farnham, Ashgate, 2011, 164, nota 6; Leena Mari Peltomaa, Andreas Külzer, Pauline Allen (eds.), PRESBEIA THEOTOKOU. The Intercessory Role of Mary across Times and Places in Byzantium (4th-9th Century) (Veröffentlichungen zur Byzanzforschung, Volume 39), Viena, Academia Austríaca de Ciencias, 2015. 
d.C., cuando los Padres de la Iglesia como Proclo de Constantinopla, Cirilo de Alejandría, Hesiquio de Jerusalén y otros comenzaron a elaborar Homilías laudatorias en su honor ${ }^{5}$. En el contexto de finales del siglo II, el Protoevangelio es único entre los textos canónicos y apócrifos sobre la Virgen María ${ }^{6}$.

El contenido del Protoevangelio indica el reciente interés no sólo para la narrativa de la infancia de la Virgen, sino también el interés para la pureza que se requería para su papel como madre de Jesucristo ${ }^{7}$. Cada detalle en la narrativa incluyendo la sterilidad de sus padres y su Concepción (haciendo eco las narrativas por los Profetas del Antiguo Testamento, como esas narrativas por Isaac y Samuel $^{8}$ ), la prevención cuidadosa de María por parte de Ana de cualquier contaminación externa y la dedicación de María al Templo de Salomón a la edad de tres años, donde ella "recibió alimento a la mano de un ángel", refuerza el mensaje central del texto, a saber, que esta doncella esta destinada y es capaz de convertirse en la madre de Cristo. Además, el autor destaca la pureza de la Virgen

5 Especialmente CPG 5248, 5800-5804, 6569-6570. Para autores tempranos de Homlías Marianas y su autoría relativa, véase ACO. vol. 1, I.2., 102-104 (Cyril of Alexandria); N. (Padre Máximo) Constas, Proclus of Constantinople and the Cult of the Virgin in Late Antiquity, Leiden, 2003, pp. 128-272; M. Aubinau, Les homélies festales d'Hésychius de Jérusalem. vol. 1 (Subsidia Hagiographica 59), Bruselas, 1978, pp. 158-168, pp. 194-204. Otros autores tempranos que han escrito Homílias sobre la Virgen son Basilio de Seleucia, pseudo-Crisóstomo, pseudo-Epifanio etc. Sobre una visión general de la homilética mariana, véase R. Caro, La homilética mariana en el siglo V 3 vols. (Marian Library Studies 3), Dayton, 1971-1973.

6 Es cierto que otros textos apócrifos tratan de la Virgen o de la infancia de Cristo, pero ninguno de estos textos, por lo que sabemos, trata tanto extensamente de la Virgen. Tales textos apócrifos son el Evangelio de los Hebreos o el Evangelio de los Ebionitas, como también textos existentes como la Ascensión de Elías o el Evangelio de Tomás.

7 Para más información sobre este material apócrifo, véase Andrew Louth, "John of Damascus on the Mother of God as a link between humanity and God", en L. Brubaker and M. Cunningham (eds.), The Cult of the Mother of God, pp. 154156.

8 Véase, Gn 21; 1 Sm (1 Re 70) 1.

9 Protoevangelio 8.1. 
durante el parto al narrar el examen del cuerpo de la Virgen María por la partera Salomé ${ }^{10}$, después de que haya dado a luz a Cristo. Un otro aspecto del Protoevangelio, que merece ser mencionado aquí, es que esto ha sido probablemente compuesto en un contexto de controversia. El énfasis del autor sobre la natividad de María puede ser apologético, particularmente como una respuesta contra la crítica pagana y judía del cristianismo, que dudaron la virtud de María y las circunstancias alrededor de la natividad de Cristo ${ }^{11}$.

A pesar del conocimiento de Orígenes y Clemente de Alejandría sobre el Protoevangelio, parece que los Padres de la Iglesia no estaban dispuestos a otorgar tanta autoridad en un texto apócrifo, que difería enormemente de la narrativa de los Evangelios canónicos. Clemente confirma en una base teológica la virginitad de María durante su parto a Cristo, cuando él se refiere a la narrativa de la partera Salomé con precaución

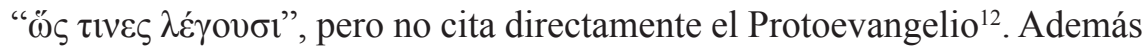
de esto, la única referencia para el texto en la literatura patrística temprana es un resumen detallado que aparece en el comentario del Libro de Génesis, o el Hexaemeron, y se atribuye a Eustacio de Antioquía, pero fue probablemente compuesto por un autor anónimo, del siglo IV o $\mathrm{V}^{13}$. Sin embargo, si la recepción del texto por los Padres fue lenta, se difundió ampliamente no sólo en las comunidades cristianas de habla griega desde al menos el siglo IV, sino también en las Iglesias Orientales ${ }^{14}$. El

10 Protoevangelio 20.1.

11 Véase, p.ej., la referencia de Orígenes a la acusación de Celso (a traves de un judío imaginario) que la madre del Señor fue expulsada por su "esposo", el carpintero José, como ella fue condenada por adulterio. Véase Orígenes, Contra Celsum I.28; M. Borret, Origène. Contre Celse (SC 132) 2 volúmenes, París, 1967, vol. 1, pp. 150-152. Para más información sobre el tema véase J.K. Elliott, "Mary in the apocryphal New Testament" en C. Maunder (ed.), The Origins of the Cult of the Virgin Mary, London \& New York, 2008, especialmente pp. 5960 .

12 Clemente de Alejandría, Stromata 7.16.93, Allan de Boulluec (ed.), Les Stromates. Stromate VII (SC 248), París, 1997.

13 CPG 3393, P.G. 18, cols. 708-793, especialmente cols. 772-776.

14 Un número de testigos tempranos, entre ellos principalmente el papiro Bodmer V, sugiere la difusión del Protoevangelio en el griego ya en el cuarto siglo. Tenemos traducciones a partir de este período en adelante en el siríaco, el 
Protoevangelio se ocultó en gran medida en el oeste cristiano a causa del pasaje en el que se dice que José tenía cuatro hijos de un matrimonio anterior (9.2). Más tarde, ese signo contencioso fue reemplezado por textos latinos como el Evangelio de pseudo-Mateo. Por lo tanto, es posible que mientras el Protoevangelio estaba conocido en grupos familiares y no familiares de la Iglesia Oriental, su estado, como una fuente narrativa y teológica por el honor de la Virgen, permanezca todavía abierto para debate ${ }^{15}$.

La situación comenzó a cambiar a partir de mediados des siglo VI, cuando los autores de textos litúrgicos, con primer auror Romano el Mélodo, comenzó a explotar el Protoevangelio por inspiración. Romanos parece ser el primero himnógrafo que utiliza el texto apócrifo como una fuente narrativa en su Kontakion sobre la Natividad de la Santísima Virgen. ${ }^{16}$ Aunque el himno comienza con la glorificación de la Natividad de la Virgen María por padres estériles, Joaquín y Ana, que también cubre su consecración al Templo y su nutrición por "la mano de un ángel”, así como su compromiso con José cuando ella llegó a la edad de 12 años. Romano emplea alguna tipología, con referencias a Adán y Eva, Sara y Ana, dos mujeres estériles a las cuales Dios dio hijos [Gn. 21: 1-2 \& 1 Re], revelando así su conocimiento de la naturaleza intertextual del Protoevangelio.

El asunto que imediatamente surge es por qué en la primera mitad del siglo VI Romano el Mélodo aceptó el testimonio de un texto apócrifo que hasta entonces no había recibido una recognición oficial ${ }^{17}$. La

etíope, el georgiano, el sahídico, el eslavo eclesiástico, el armeno y posiblemente el latín.

15 Es digno de mención, p.ej., que Atanasio de Alejandría no utilice el Protoevangelio al describir a María como una joven virgen piadosa en la Primera Carta a las Vírgenes. Véase D. Brakke, Athanasius and Asceticism, Baltimore and London, John Hopkins University Press, 1995, pp. 277-299.

16 P. Maas-C.A. Trypanis (eds.), Sacti Romani Melodi Carmina Cantica. Cantica Genuina, Oxford, 1963, pp. 276-289.

17 Es signo de atención, p.ej., que las Homilías marianas del siglo V y el Himno Acatisto no utilizcan expícitamente el Protoevangelio para inspiración. Para las Homilías marianas del siglo V, véase M. Cunningham, "The Meeting of the Old and the New: The Typology of Mary the Theotokos in Byzantine Homilies and Hymns" en R.N. Swanson, The Church and Mary (Studies in Church History 39), Boydell \& Brewer, 2004, pp. 53-54. Del Himno Acatisto, véase L.M. Peltomaa, The Image of the Virgin Mary in the Akathistos Hymn, Leiden, Brill, 2001. 
respuesta más obvia es que la institución de las fiestas marianas comenzó aproximadamente en esa época. Dado que los Evangelios no proporcionan una narrativa completa sobre la vida de la Virgen, fuentes apócrifas, como el Protevangelium Iacobi o narraciones para la Dormición de la Virgen, sirvieron para llenar este vacío. Romano realmente considera que su

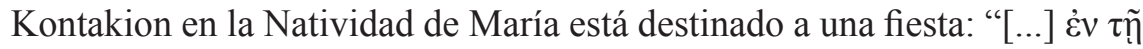

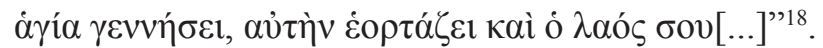

El Kontakion del siglo VI es una sola pieza de evidencia. Sólo durante el siglo VIII con la aparición de numerosas Homilías e himnos para la fiesta de la Natividad de la Virgen por autores como Juán Damasceno y Andrés de Creta podemos estar seguros que esa fiesta fue ampliamente celebrada a través del imperio bizantino y de Palestina ${ }^{19}$. Lo mismo ocurre con otras fiestas marianas, entre ellas la fiesta de los padres de las vírgenes Joaquín y Ana (9 de septiembre), las fiestas de la Presentación de la Virgen María (21 de noviembre) y la Concepción de Santa Ana (9 de diciembre). Lo sorprendente de todos los textos litúrgicos relacionados con las fiestas anteriores, que comenzaron a ser sintetizadas desde los principios del siglo VIII, es que ellas explotan explícitamente el Protoevangelio para la narración de la infancia de María y por inspiración teológica. Parece que por lo menos a principios del siglo VIII el Protoevangelio asumió la aceptación

18 Maas-Trypanis, Sancti Romani Melodi, p. 276. 3-4.

19 El himno anterior ha llevado algunos estudiosos a aceptar como fecha para la introducción de la fiesta de la Natividad de la Virgen en el calendario litúrgico constantinopolitano. Véase T. Antonopoulou, The Homilies of the Emperor Leo VI, Leiden, Brill, 1997, p. 163, nota 5. Sin embargo, otros estudiosos, como Averil Cameron, ha argumentado que la festividad de la Natividad de la Virgen haya sido introducido en el calendario litúrgico por el emperador bizantino Justino II. Véase Averil Cameron, "Images of authority: élites and icons in late sixth-century Byzantium", Past and Present 84/1(1979), pp. 3-35. J. Grosdidier de Matons evita relacionar el kontakion de Romano con la recientemente establecida fiesta mariana de la Natividad, en la que él propone que la fiesta de la Natividad haya sido introducida en el calendario eclesiástico por el emperador bizantino Mauricio (582-602 d.C.), simultáneamente con la introducción de la fiesta de la Dormición. J. Grosdidier de Matons, "Liturgie et hymnographie: kontakion et canon", DOP 24/25 (1980-1981), pp. 31-43. Véase también J. Lafontaine-Dosogne, Iconography of the cycle of the life of the Virgin, en P. Underwood (ed.), The Kariye Djami. Studies in the Art of the Kariye Djami and its Intellectual Background. v. 4. London 1975, p. 164. 
completa en la tradición litúrgica y teológica bizantina. La aceptación de los textos apócrifos sobre la Dormición de la Virgen María existía también a finales del siglo VI y a principios del siglo VII, aproximadamente en el mismo período en el que el emperador Mauricio (582-602 d.C.) introdujo la fiesta mencionada en el Calendario litúrgico ${ }^{20}$. Predicadores tales como Juan de Tesalónica, Modesto de Jerusalén, Theotecno de Livia usaron varias narraciones que circulaban este período, aceptándolas aparentemente como parte de una tradición santa ${ }^{21}$.

\section{EI Protevangelium Iacobi y las fiestas marianas}

Volviendo ahora al uso del Protoevangelio en la creación de las fiestas marianas del período bizantino medio, propongo mirar estos textos evidentemente influidos por la narrativa apócrifa del siglo segundo para la conmemoración de las fiestas institucionalizadas de la Concepción, de la Natividad y la Presentación de la Virgen María. Como se dijo anteriormente, las fiestas marianas no fueron un objeto de investigación en los textos litúrgicos de este período, con la excepción del Kontakion de Romano sobre la Natividad de la Virgen. En la discusión que sigue nos vamos a mirar el uso del Protevangelium sobre las anteriores fiestas marianas principales- fiestas que honran la infancia de la Virgen María- en la obra de seis mayores autores de Homilías marianas del período bizantino medio: Andrés de Creta, Juan de Damasco, Germano I de Constantinopla, Juan de Eubea y Cosme Vestitor. Dentro de un marco festivo, se considerarán diversos aspectos, entre ellos el uso del Protoevangelio como herramienta narrativa, la referencia a la importancia teológica y el desarrollo de cierta tipología.

20 Según el historiador bizantino del siglo XIV Nicéforo Calixto Xanthopoulos, la fiesta de la Dormición de la Virgen (15 de agosto) ha sido introducida durante el reinado de Mauricio (582-602). Véase Historia Eclesiástica 17,28, P.G. 147,

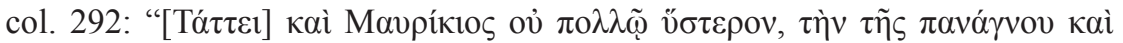

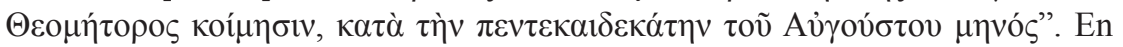
cuanto a las diversas tradiciones que existen entre los relatos de la Dormición, véase S. Shoemaker, Ancient Traditions of the Virgin Mary's Dormition and Assumption, OUP, 2002.

21 Cf. Brian J. Daley, On the Dormition of Mary. Early Patristic Homilies, Crestwood NY, 1998. 
Para comenzar con la fiesta de la Concepción de la Virgen María sólo una homilía se sobrevive por un predicador del siglo VIII, Juan de Eubea. Que esta homilía se destinó especialmente para la fiesta de la Concepción, el autor clarifica en un pasaje describiendo diez grandes fiestas del año litúrgico, de las cuales la Concepción es la primera:

"La primera de las fiestas notables son aquélla en las que Joaquín y Ana recibieron la buena noticia del nacimiento de la María, completamente pura y ella que dio a luz a Dios. Y después de esto, [allí viene] su Natividad sagrada" (según Cunningham, Wider than heaven, p. 182) ${ }^{22}$.

En una parte de su Homilía Juan pide a su audiencia que recuerde la historia de Joaquín y Ana, resumiendo brevemente el dolor de la pareja a causa de su infertilidad, las oraciones a Dios y la concepción milagrosa que siguió $^{23}$. En su tratamiento del material narrativo del Protoevangelio, el

22 Juan de Eubea, De la Concepción del Santísima Virgen, P.G. 96, col. 1476 C:

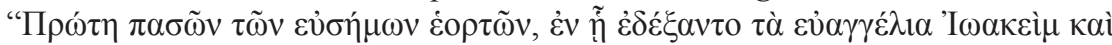

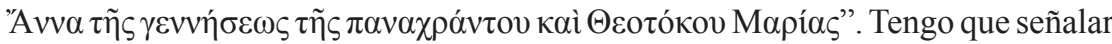
desde el principio que las traducciones al inglés de las citas griegas han sido extraído del estudio de M. B. Cunningham, Wider than heaven. Eighth-century Homilies on the Mother of God, (Popular Patristics Series 35), Crestwood, New York, St. Vladimir's Seminary Press, 2008. Es considerable que Juan identifica en su homilía diez grandes fiestas, fiestas referidas al Señor y fiestas referidas a Theotokos. La lista que cita parece excéntrica, ya que se incluye la fiesta de la Concepción de María. Es probable que el hecho anterior refleje el origen provincial del predicador y escritor, y las variaciones de las prácticas litúrgicas que aún existían en el siglo VIII. Para varias discusiones sobre la ascendencia griega o siríaca de Juan de Eubea, véase F. Dölger, "Iohannes von Euboia", en Anal Boll 68(1950), pp. 5-26. F. Halkin, "La passion de Ste Parascève par Jean d'Eubée", en P. Wirth (ed.), Polychronion. Festschrift für Franz Dölger, Heidelberg, 1966, pp. 231-237.

23 Uno de los elementos más extraños de esta Homilía es que el autor a menudo se desvía del tema principal, discutiendo figuras del Antiguo Testamento, como Rubén, el hijo mayor de Jacob, quien fue denunciado por haber profanado el lecho de su padre (Ge 49,4: Impetuoso como las aguas, no serás el principal, por cuanto subiste al lecho de tu padre; entonces te envileciste, subiendo a mi estrado). Esta referencia se inspira en el hecho de que su homónimo es el judío que se resistió a Joaquín diciéndole que no podía ofrecer regalos al Templo debido a su esterilidad. Cf. Protoevangelio 1.2. 
predicador subraya sobro todo su carácter dramático, utilizando una serie de recursos retóricos para elevar el podero influyente de su homilía. Así, él comienza a exclamar: “¡He aquí Joaquín y Ana! [...] He aquí las buenas noticias de la felicidad en un jardín [...]"24, antes de continuar repitiendo la historia de los anuncios separados centrados en el desarrollo emocional de cada persona. Es notable el interés de Juan de Eubea para Anna en su homilía. Comentando sobre las acciones de Ana, ya que Joaquín corre de la casa para orar en el desierto durante cuarenta días, Juan escribe:

"Entonces Anna, al contemplar el retraso de su esposo, empezó a llorar a sí misma con un suave lamento ya decir: ‘¿Qué significa este retiro de mi querido esposo?’ O ‘¿Cuál es el significado de este retraso?' Lo veo, no es bueno [...] ¿Pero por qué voy a llorar, a menos que yo sea tanto viuda como sin hijos? Si tuviera un rodaje, no sentiría tal dolor con respecto a la raíz. Si el hombre que deseaba desde mi juventud estuviera presente, habría alguna expectativa incluso con respecto al rodaje. ¡Ay, qué voy a hacer yo! [...] ¡Ay !, ¿cómo voy a llorar como un cadáver? ¡Pero no he visto tu tumba! ¿O voy a esperar como si te hubieras ido a una tierra lejana? Pero nadie me ha informado de que ha encontrado a mi señor. ¡Ay !, ¿quién me informará dónde está mi compañero y consorte, dónde está el descendiente y seguidor de Abraham?" (según Cunningham, Wider than heaven, p. 180) ${ }^{25}$.

En su intento de motivarse a su congregación, -y especialmente a los miembros femeninos de esa congregación-, Juan inventa uno monólogo en el que Ana expresa desesperación, duda y un fuerte afecto por su marido

24 Juan de Eubea, De la concepción de la Santísima Virgen P.G. 96, col. 1465 A

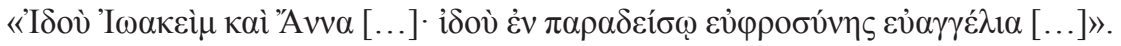

25 Juan de Eubea, De la concepción de la Santísima Virgen P.G. 96, col. 1472

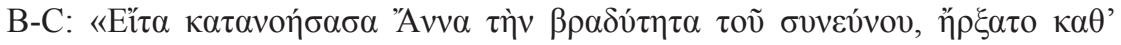

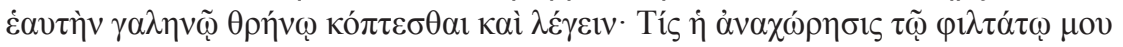

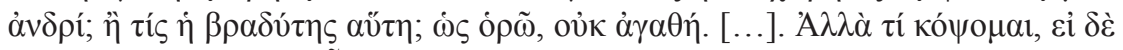

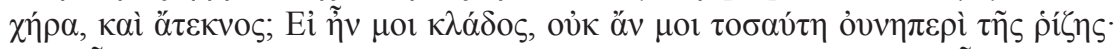

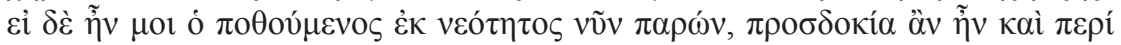

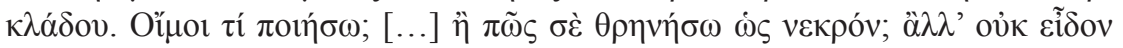

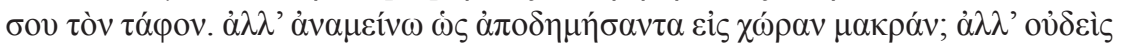

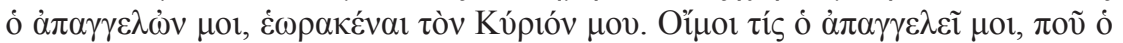

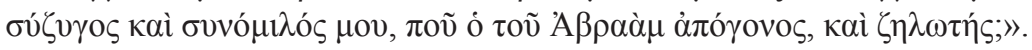


ausente. El monólogo es seguido por pasajes en los que el predicador profiere exclamaciones de alabanza a la pareja santa, ya que comienza con la interpretación exegética de nombres bíblicos o eventos sugeridos por el texto y continúa su narrativa de las reacciones emocionales de Joaquín y Ana a la promesa de un niño. Él concluye esta parte de su homilía con las siguientes líneas:

"Entonces, cuando el justo Joaquín también recibió las buenas nuevas de la concepción desde sus lomos, comenzó a preparar doblemente y triplicar las expresiones de alegría, y multiplicando estas diez veces, se regocijó y se alegró. Y en efecto, habiendo cumplido todo según su costumbre, ofreciendo dones $\mathrm{y}$ sacrificios, concibió la mujer estéril. Y ambos esperaban el fruto del nacimiento, cualquiera que fuese el resultado" (según Cunningham, Wider than heaven, p. 184) ${ }^{26}$.

Después del retato de la concepción y del nacimiento de la Santísima Virgen, Juan de Eubea vuelve su atención al cuento, que también fue relatado en detalle en el Protoevangelio, de su dedicación al Templo. ${ }^{27}$ En esta parte de su homilía el predicador decide centrarse su atención en el simbolismo numérico y la tipología del relato apócrifo del siglo II. El simbolismo numérico utilize un elemento que ya está presente, aunque en una forma menos desarollada, en el Protoevangelio. Al comentar sobre el hecho de que María fue llevada al Templo a la edad de tres años, Juan concluye que esta opción era un símbolo de la Santa Trinidad. Entonces Juan va a una comparación de María, el templo vivente, y del Templo que es hecho por piedra. Lo anterior recuerda el Salmo 44(45) y la imagen de la

26 Juan de Eubea, De la concepción de la Santísima Virgen P.G. 96, col.

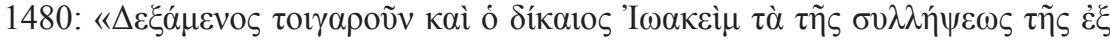

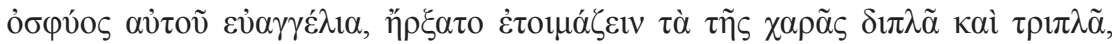

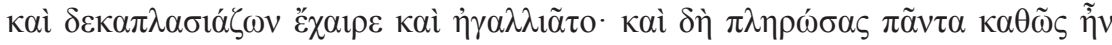

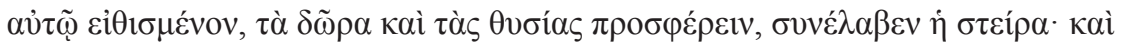

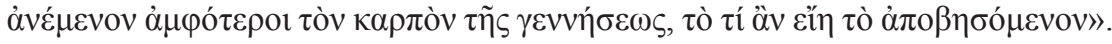

27 Es común en este período de encontrar autores que se tratan en sus homilías marianas de más sujetos. Véase, Andrés de Creta, De la Natividad de la Santísima Virgen I, P.G. 97, especialmente col. 820, en que el predicador se trata de la Presentación al Templo. 
princesa con sus hijas vírgenes, que fueron llevadas ante el Rey ${ }^{28}$, un texto relacionado con la fiesta de la Presentación de la Virgen, que influyó más tarde los textos homiléticos y himnográficos.

Es interesante observar, en referencia a esta temprana homilía sobre la fiesta de la Concepción de María, que la mayoría de los datos, que continuarán a ser presentados en las homilías, ya están presentes. Estas homilías incluyen el desarollo dramático de la historia del Protoevagelio con monólogos y diálogos inventados, exploración de la tipología del Antiguo Testamento que prefigura estos eventos, así como la exegesis intertextual basada especialmente en los Profetas y los Salmos. Otros rasgos del estilo homilético de Juan de Eubea son también evidentes en esta homilía específica, como su tendencia a "participar" activamente en cada homilía y su polémica antijudía. Sobre todo, debemos señalar la dependencia de Juan de Eubea en el Protoevangelio como la fuente auténtica para los acontecimientos celebrados en esta fiesta.

Una confidencia similar en el Protoevangelio es evidente en las numerosas homilías preservadas después del siglo VIII. Estos textos incluyen la homilía atribuida a Juan el Damasceno ${ }^{29}$ y otras cuatro, probablemente pronunciadas durante una vigilia nocturna, que han sido compuestas por Andrés de Creta $^{30}$. Cada una de estas homilías aborda el tema de la celebración algo diferente y algunos autores hacen un mayor uso del Protoevangelio que otros.

El sermón de Juan el Damasceno sobre la Natividad es una obra maestra de la eloquencia oracional de Juan, elogiando este gran evento como "la Natividad de la alegría para el mundo entero" 31 . Aunque esta homilía se centra en el significado teológico de la fiesta que en el relato de

28 Juan de Eubea, De la Concepción de la Santísima Virgen, P.G. 96, col. 1481.

29 CPG 8060. B. Kotter (ed.), Die Schriften Des Johannes von Damaskos (Patristische Texte und Studien 7, 12, 17, 22, 29), 5 volúmenes, Berlin-New York, Walter de Gruyter, 1969-1988, vol. 5, 149-150. P. Voulet, S. Jean Damascène, Homélies sur la nativité de la dormition (Sources Chrétiennes 80), Paris, Editions du Cerf, 1961, pp. 46-78.

30 CPG 8170-8173. P.G. 97, cols. 805-881.

31 La autenticidad de esta homilía es controversial. Véase Kotter, Die Schriften, v. 5, pp. 149-150; A. Louth, St. John Damascene. Tradition and Originality in Byzantine Theology, Oxford, 2002 p. 226. 
Protoevangelio, ello se refiere repetidamente al texto apócrifo, al elogiar la integridad y virtud de los padres de María, Joaquín y Ana, y celebra su nacimiento. Es sorprendente, desde un punto de vista teológico, que el autor se centre también en los aspectos paradójicos y naturales de la concepción de María. En la primera sección de la homilía, Juan el Damasceno escribe: "Pero ¿por qué ha nacido la Virgen Madre de una mujer estéril? Para lo único que es nuevo bajo el sol, la culminación de milagros, el camino tenía que ser preparado por medio de milagros, y lo que era mayor tenía que avanzar lentamente desde lo más humilde. Y tengo otra razón más exaltada y divina. La naturaleza ha sido derrotada por la gracia y se encuentra temblando, ya no está listo para tomar la iniciativa. Por lo tanto, cuando la Virgen portadora de Dios estaba a punto de nacer de Ana, la naturaleza no se atrevió a anticiparse a la rama de la gracia; sino que permaneció sin fruto hasta que brotó su fruto" (según Cunningham, Wider than heaven, p. 54) $)^{32}$.

Al describir la concepción y el nacimiento de María, el predicador se centra también en el proceso completamente natural de la reproducción sexual que tuvo lugar cuando Joaquín y Ana se reunieron después de su milagrosa anunciación:

“¡Oh, la mayoría de los lomos benditos de Joaquín, de los cuales se envió una semilla totalmente sin mancha! ¡Oh vientre de renombre de Ana, en el que lentamente, con adiciones de ella, creció un niño santo, y una vez que había tomado forma, nació!" (según Cunningham, Wider than heaven, p. 54) ${ }^{33}$.

32 Juan Damasceno, De la Natividad de la Virgen, Kotter, Die Schriften, v. 5, p. p.

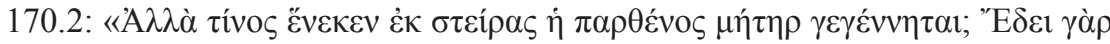

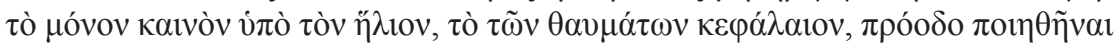

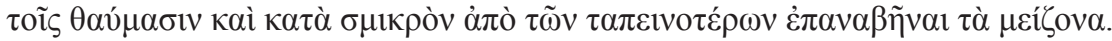

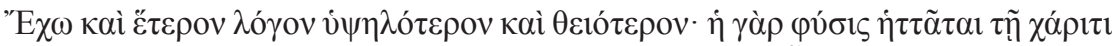

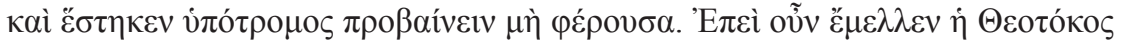

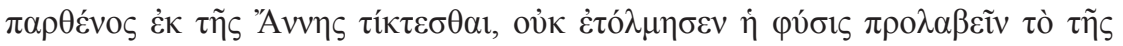

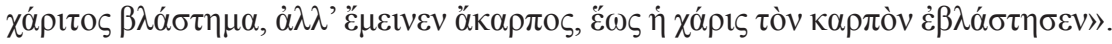

33 Juan Damasceno, De la Natividad de la Virgen, Kotter, Die Schriften, v.

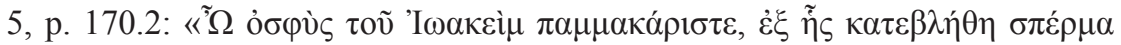

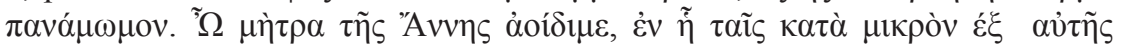

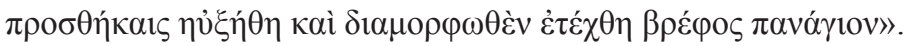


Este pasaje, que refleja la creencia antigua y medieval de que el feto crece a partir del esperma masculino con "adiciones", en forma de sangre, añadida lentamente por la madre, enfatiza deliberadamente el vínculo de María con la humanidad ${ }^{34}$. Esta preocupación se refleja en el primer discurso de Andrés sobre la Natividad, en el que escribe, aún más gráficamente:

"Así, el poder que nunca perdura vino muy pronto a aquellos que imploraron y suplicaron al Ser Divino. Le estimuló a la fecundidad ya ella en la producción de un niño; y habiendo entretanto rociado los pasajes marchitados de los órganos reproductores con los jugos de la producción de esperma, ¡los trajo de la infertilidad a la productividad!" 35 (según Cunningham, Wider than heaven, p. 79).

La relación entre la concepción física y el nacimiento de María y la celebración de estos eventos también se recalca en muchos sermones relacionados a la Natividad. Andrés de Creta, por ejemplo, escribe sobre la celebración de la encarnación de Cristo, que comenzó con el nacimiento de la Virgen María, como sigue:

"Por lo tanto, que todas las cosas se regocijen hoy y dejen que la naturaleza salte: '¿Que el cielo se regocije y que llueva la lluvia!' (Is 45.8). ¡Que las montañas caigan la dulzura y las colinas la exaltación! ¡Que cada alma agradecida, por lo tanto, ahora baile, y que la naturaleza invite a la creación a su propia renovación y restauración!" (según Cunningam, Wider than heaven, p. 74) ${ }^{36}$.

34 Sobre los puntos de vista patrísticos y bizantinos de la concepción y del nacimiento, véase: L. Brusson, M.H. Congourdeau, J. L. Solère (eds.), L'embryon: formation et animation. Antiquité grecque et latine. Traditions hébraique, chrétienne et islamique (Histoire des doctrines de l'antiquité classique 38), París, Librairie Philosophique J. Vrin, 2008.

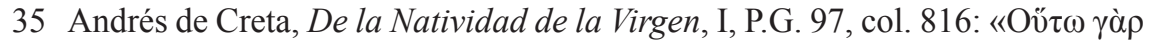

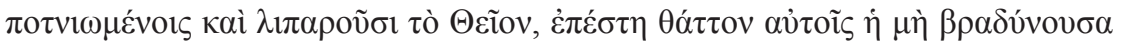

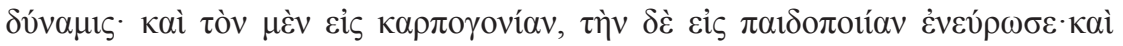

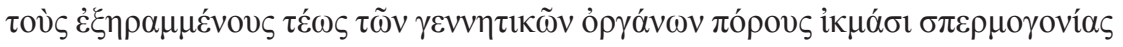

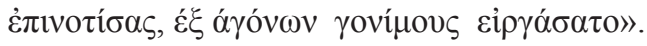

36 Andrés de Creta, De la Natividad de la Virgen María, I, P.G. 97, col. 809 C:

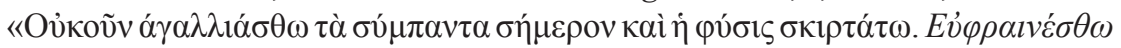


Estas imágenes recuerdan el lenguaje usado en los salmos y los libros proféticos del Antiguo Testamento. Los predicadores bizantinos usaban una forma intertextual de exégesis bíblica, que vinculaba la creencia en la presencia de Dios a través de la creación, expresada en el Antiguo Testamento, con la doctrina cristológica calcedoniana. Por otra parte, la excitación y la emoción que caracteriza a los sermones del medio bizantino festal es sorprendente ${ }^{37}$.

Otro aspecto de la exégesis homilética del octavo siglo del Protoevangelio es el énfasis en la virtud y buen linaje de Joaquín y Ana. Las razones de esto son obvias: para ser digna de su próxima condición de Madre de Dios, el origen de María debe ser irreprochable. Andrés de Creta y Juan de Damasco se refieren a las genealogías situadas en los Evangelios de Mateo y Lucas para demostrar que no sólo Joaquín, sino también Ana son descendientes del profeta David. Además, ellos celebran la justicia y la pureza de ambos padres. Tomando un ejemplo, Juan de Damasco exclama con un vigor emocional característico:

“¡Oh, la más casta de las tortolitas ratas Joachim y Anna! Habiendo mantenido la ley de la naturaleza, la castidad, se te consideró digno de cosas que sobrepasan a la naturaleza; has dado a luz al mundo a una Madre de Dios que no conoce marido. Habiéndose conducido piadosamente y benditamente en la naturaleza humana, ahora han dado a luz a una hija que supera a los ángeles y tiene dominio sobre los ángeles. ¡Oh hija más hermosa y dulce! ¡Oh lirio entre las espinas engendrado de una raíz davánica más noble y majestuosa! [...] ¡Bienaventurados los lomos y el vientre de donde saliste! ¡Bienaventurados los brazos que te llevaron y los labios que probaron tus besos puros - los labios sólo de tus padres que siempre podrías ser virgen en todos los sentidos!" (según Cunningham, Wider than heaven, p. 60) ${ }^{38}$.

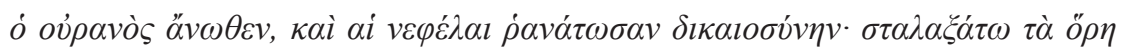

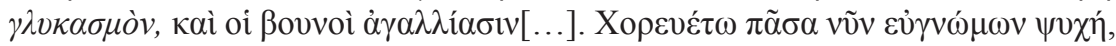

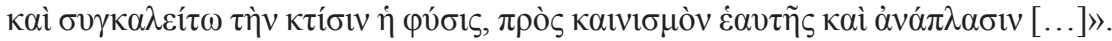

37 Para más confirmación de lo anterior, véase N. Tsironis, "Emotion and the senses in Marian homilies of the Middle Byzantine period" en L. Brubaker \& M.B.Cunningham, The Cult of the Mother of God, 2011, pp. 179-196.

38 Juan Damasceno, De la Natividad de la Virgen, Kotter, Die Schriften, v. 5, p. 
Aunque Joaquín y Ana no se mencionan en los textos canónicos del Nuevo Testamento, su posición en la parte superior de la jerarquía de los

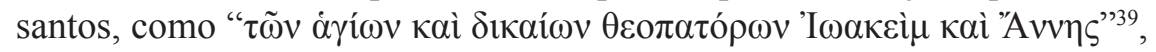
esta implicado en estas homilías.

Un autor, cuya obra sigue siendo algo descuidada por los eruditos, a pesar de su importancia como uno de los pocos predicadores seculares bizantinos, es Cosme Vestitor, que deber haber florecido en algún momento entre mediados de los siglos VIII y IX ${ }^{40}$. Cinco homilías marianas se atribuyen a Cosme: mientras que la primera homilía honre la memoría de Joaquín y $\mathrm{Ana}^{41}$, las otras cuatro homilías, que sólo se conservan en latín, se han dedicado en la fiesta de la Dorminación de María ${ }^{42}$. Cosme, al igual que sus contemporarios, hace un uso suficiente del Protoevangelio en su homilía en su comemoración de los padres te Theotokos. El predicador deja claro que este sermón es una fiesta "menor" que ya se ha celebrado el 9 de septiembre, un día después de la Natividad de María ${ }^{43}$. Así, Cosme

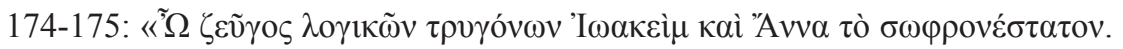

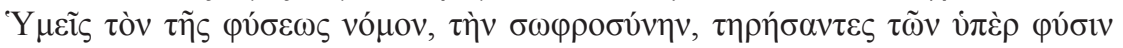

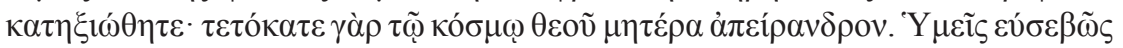

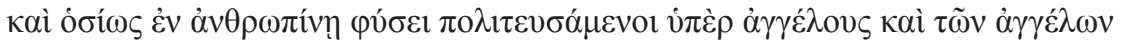

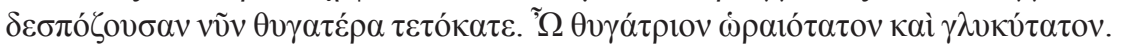

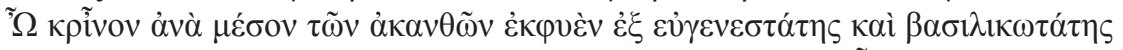

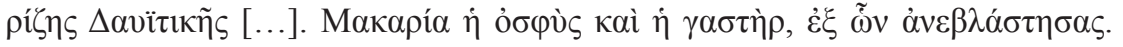

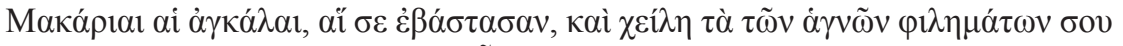

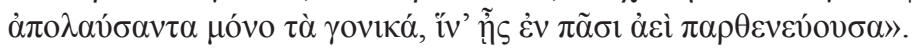

39 Estas son las palabras con las que los Santos Joaquín y Ana son honrados en la oración final de la Divina Liturgia de San Juan Crisóstomo.

40 Sobre Cosme Vestitor, véase A. Wenger, L'Assomption de la très sainte Vierge dans la tradition Byzantine du Vie aux Xe siècle (Archives de l'Orient Chretien 5), Paris, 1955, pp. 315-333.

41 CPG 8151. P.G. 106, cols. 1005-1012.

42 CPG 8155. Wenger 1955, pp. 315-333.

43 La homilía de Vestitor representa el primero texto litúrgico en honor de esta fiesta, que en el siglo X se cita en el Typicon de la Gran Iglesia de Constantinopla:

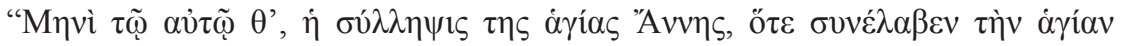

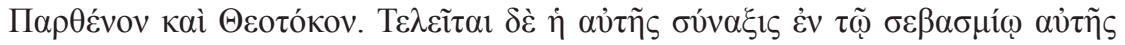

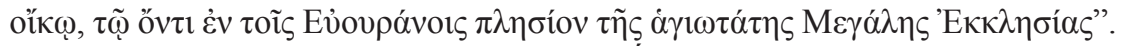
Véase J. Mateos, Le Typicon de la Grande Église: Ms. Sainte-Croix no. $40 \mathrm{Xe}$ 
escribe en su prólogo:

“Ayer el festival de la Natividad de Theotokos glorificó la celebración de la alegría cósmica para nosotros con himnos auspiciosos. Hoy es el día que ofrece acción de gracias a los progenitores de Theotokos, a través de los cuales ha comenzado el comienzo de la salvación para todos. De hecho, la fiesta de los padres es la de la hija. Porque así como un niño es glorificado también en la gloria de su madre, así también es una madre glorificada en la bendición de un niño. Ayer así fue un día que fue 'maravilloso a nuestros ojos' (ver Sal 117,113), y hoy hay felicidad en recordar a los justos con discursos de alabanza" (según Cunningham, Wider than heaven, p. 139) ${ }^{44}$.

El sermón de Kosme Vestitor para los santos Joaquín y Ana se centra principalmente en estas figuras sagradas, utilizando la información proporcionada en el Protoevangelio. Después del prólogo, al que sigue la parte del relato, Kosme ofrece chairetismoi-salutaciones en forma de "Salve" a los santos progenitores, empleando imágenes poéticas como "concha de ostra de la perla impecable", "esmeralda pura" y "jarra de agua para la sed de hijos" " Otro aspecto interesante de emplear el Protoevangelio por Kosme es su énfasis en la bondad del matrimonio, o la asociación, de Joaquín y Anna. El orador retrata esto de una manera realista, refiriéndose al dolor y a la alegría diarios de la pareja y comparando Ana con su predecesor Eva:

"Porque [Ana] estaba unida a su esposo como ayudante tanto en el vivir de virtudes como en súplicas diarias a Dios. Porque los dos se sintieron igualmente cansados en su oración

siècle (2 vols.), Roma, 1962, v. 1, p. 126. 4-7.

44 Kosme Vestitor, De los santos Joaquín y Ana, P.G. 106, col. 1005 A: “"H

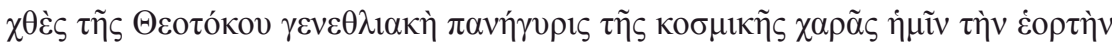

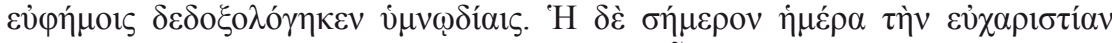

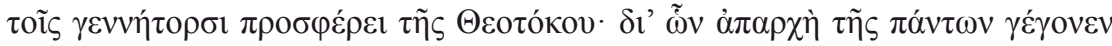

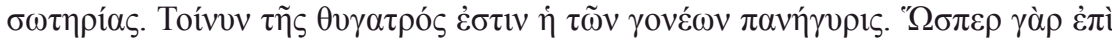

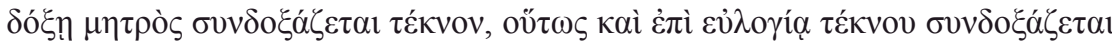

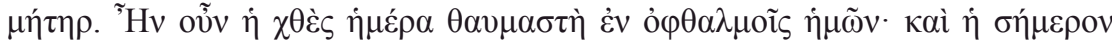

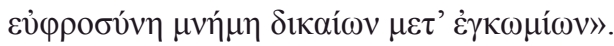

45 Kosme Vestitor, De los santos Joaquín y Ana, P.G. 106, col. 1009. 
de anhelo por un niño, de la misma manera que un granjero, junto con su esposa, cuando han trabajado alguna tierra árida, siembran la semilla y, por medio de la oración, esperan obtener una buena cosecha de Fruta. [Ana vivió] no como Eva vivió con Adán, sino como quien compartió en acción de gracias y trabajó con [Joaquín] en buenas obras espirituales; y ella era realmente una «mitad mejor» que terminó la unión con su marido perfectamente. Puesto que Eva se convirtió en el productor del dolor para el mundo mediante el fruto de un árbol, la Ana de Joaquín representó el gozo del Creador por medio del fruto de su vientre" (según Cunningam, Wider than heaven, p. 140) $)^{46}$.

En cuanto a la fiesta de la Entrada de María al Templo, es importante señalar que los dos sermones atribuidos a Germano de Constantinopla deben ser los primeros textos litúrgicos que fueron compuestos para esta fiesta. ${ }^{47}$ Aunque se ha argumentado que esta fiesta fue introducida en el calendario litúrgico de Constantinopla durande el reinado del emperador Justiniano I (527-565) ${ }^{48}$, es más seguro, debido a la falta de otros textos litúrgicos, concluir que la fiesta de la Entrada de la Virgen surgió casi dos siglos más tarde, en algún momento alrededor del principio del siglo VIII ${ }^{49}$.

46 Kosme Vestitor, De los santos Joaquín y Ana, P.G. 106, col. A-B: «Ov̉ yà $\rho$

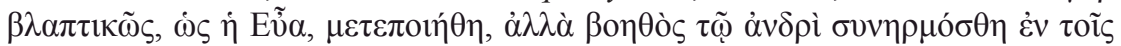

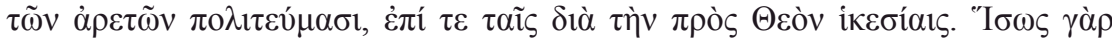

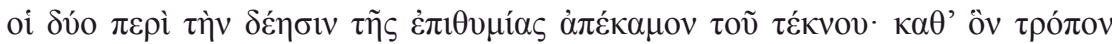

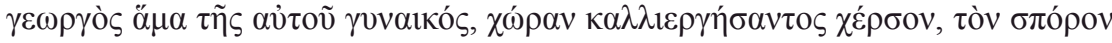

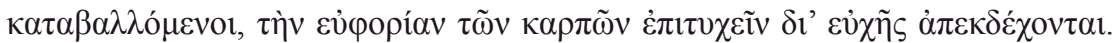

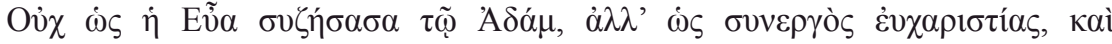

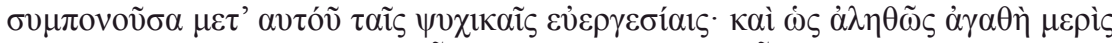

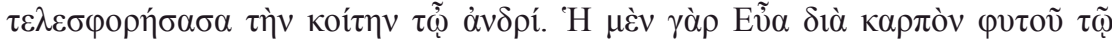

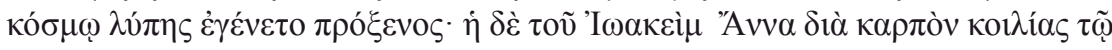

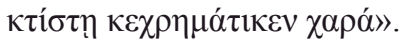

47 CPG 8007-8008. P.G. 98, cols. 292-320.

48 Cf. p.ej. M. Baker, Justinian's 'New Church' and the Entry of the Mother of God into the Temple, Sourozh 103(2006), pp. 15-33.

49 Cf. S. Vailhé, La féte de la presentation de Marie au temple, EO 5(19011902), pp. 212-218. 
El Protoevangelio proporciona el relato de esta fiesta y hace el mismo para las fiestas de la Concepción y la Natividad de María. Predicadores y himnógrafos del siglo VIII en adelante decoraron este relato con tipología, desarollando la tipología del "templo" para la Virgen María, cuenta dramática y alusiones a los Salmos.

Dejando de lado la cuestión de la autenticidad, con énfasis en los dos sermones de la Presentación de la Virgen atribuida a Germano, Patriarca de Constantinopla ${ }^{50}$, simplemente observamos que estos sermones difieren en estilo y contenido. Mientras que el primer sermón se haya compuesto en un alto estilo retórico con largos períodos y neologismos, la segunda homilía es más característica por su alto estilo literario del griego Koiné que caracteriza la mayor parte de la producción homilética del Patriarca. El contenido de la primera homilía es también más teológico y panegírico que el contenido de la segunda homilía, que se centra más en aspectos narrativos y dramáticos de la historia apócrifa. Por último, es sorprendente que la segunda homilía, como tantas otras homilías marianas festales de principios del siglo VIII, se desvíe del tema de la fiesta de la Presentación, empleando tipología, profecías e imágenes poéticas, para enfatizar la preparación de la Virgen y su próximo papel como el "templo vivo" de Dios. Otro texto homilético de principios del siglo VIII, el primer sermón de Andrés de Creta para la Virgen María, discute también en la parte conclusiva el tema de la Entrada de María al Sanctasanctórum ${ }^{51}$. Aquí el predicador se concentra principalmente en volver a contar la cuenta del Protoevangelio, aunque, como Germano de Constantinopla, pone en el énfasis en las alusiones teológicas sobre el "templo vivo" de Dios.

Vale la pena considerar el tratamiento dramático de la cuenta del Protoevangelio, especialmente en el segundo sermón de Germano sobre la Presentación de la Virgen Santa. Esta homilía destaca los brotes emocionales de personas involucradas en la historia, incluyendo a Santa Ana y al sumo sacerdote Zacarías, cuando recibe al Divino Infante. Después de describir la procesión a la iglesia, acompañada de vírgenes llevando antorchas [cf. Salmo 43 (44)], el predicador inventa un diálogo entre Ana y Zacarías, en el que él pregunta a la madre de María por su familia y explora las razones por las que Anna llevó a su hija al Templo. Anna responde con un

50 Varios académicos han aceptado la autenticidad de ambas Homilías, mientras que otros han rechazado su autenticidad.

51 CPG 8170. P.G. 97, cols 805-820. 
informe completo sobre su desesperación para ser estéril, sus oraciones a Dios y su alegría por la concepción milagrosa y, finalmente, la decisión de ofrecer a su hija a Dios. Zacarías emite palabras de alegría y alabanza, inventadas por el predicador, presentando no sólo su reacción personal al acontecimiento, sino también el significado teológico en la historia de la remisión de los pecados:

"Oyendo estas palabras, Zacarías respondió de inmediato a Ana, diciendo: ‘ ¡Bendita sea tu raíz, toda honrada! ¡Glorificado sea tu vientre, amado por tu marido! ¡Más glorioso es tu ofrecimiento, amante de Dios!' Entonces, abrazando al niño con gran alegría, él la llevó con ansiedad al santo de los santos, tal vez diciéndole palabras como éstas a ella, “¡Ven, cumplimiento de mi profecía! Ven, la realización de las promesas de Dios! Ven, sello de su pacto! ¡Ven, logro de sus propósitos! ¡Ven, manifestación de sus misterios!' (según Cunningam, Wider than heaven, p. 168) ) $^{52}$.

Ni este documento ni el primer discurso atribuido a Germano, descuidan los aspectos simbólicos o tipológicos de esta historia. Algunos detalles exegéticos se desarrollan aquí por primera vez, mientras que otros detalles ya se han utilizado para honrar otras fiestas marianas. En su primer sermón a la Virgen, por ejemplo, Germano desarrolla tres implicaciones trinarias del número tres, como se menciona en el relato del Protoevangelio para la Presentación de María y ya citado, como vimos anteriormente, en el sermón de Juan de Eubea para la Concepción de María. Aquí, la edad de tres años de la Virgen se refiere a las tres piedras utilizadas por David para derrotar Goliat [1 Reyes. (1 Sam.) 17,40] $]^{53}$, los tres días que el

52 Germano de Constantinopla, De la entrada al templo II, P.G. 98, col.

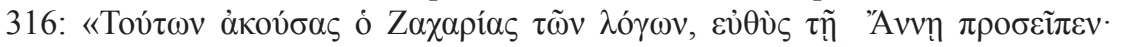

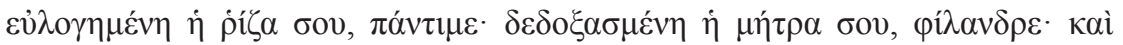

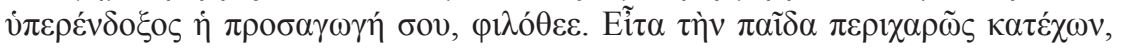

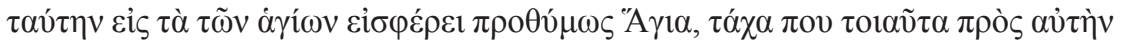

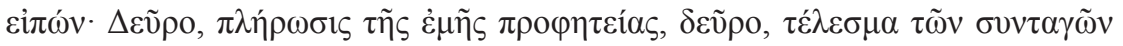

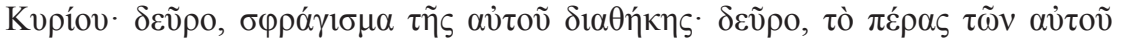

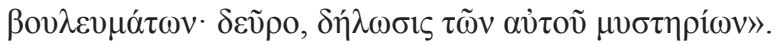

53 Mientras que el Antiguo Testamento identifica esencialmente cinco piedras de David, la iconografía bizantina lo representa con tres piedras, tal vez por el simbolismo de la Santísima Trinidad. 
profeta Jonás en el vientre de la ballena [Jonás 1,17], los tres jóvenes en el hornomardiente [Daniel 3, 20-27], etc. Sobre todo, Germano se refiere a la Trinidad, en la que tres personas "se unieron en su totalidad de manera consustancial como por un número perfecto en la unidad no confundida, o recogida" ${ }^{54}$. La transición del templo sin vida del viejo perdón a la animada Templo del nuevo perdón se destaca en las siguientes líneas:

"Hoy la mesa sagrada del templo comienza a hacerse espléndida, habiendo asumido la transferencia a sacrificios sin sangre por la participación y el abrazo más dulce del pan celestial y sustentador de vida de una mesa de veneración divina. Hoy ella sola está dedicada al lugar de la propiciación para las inundaciones de errores que han derribado a los mortales, siendo llamado un lugar de propiciación nuevo, más divino, que no es hecho por manos" (según Cunningam, Wider than heaven, p. 147) (55 $^{55}$

Aquí, como en otras fiestas marianas, la tipología se puede emplear alternativamente: la Virgen María no es sólo un "templo", sino también una "mesa sagrada" o altar, que contiene el pan vivificante, Cristo. A1 final de este sermón, como en el caso de algunos otros textos literarios del mismo género, una serie de salutaciones y tipología proporciona imágenes de María. La Santísima Virgen es "la nube luminosa que deja caer gotas de rocío espiritual y divino sobre nosotros", "el paraíso más delicioso y racional de Dios", "el palacio del Gobernante, Dios, que fue sagrado, inmaculado y más puro", "el nuevo Sión y la divina Jerusalén”, "el santo trono de Dios", etc. ${ }^{56}$. Aunque lo anterior es la tipología estándar para la Virgen María, el predicador adapta éstos en todo caso en el tema de la fiesta de la Presentación de la Virgen, diciendo que "el monte de Dios" produce

54 Germano de Constantinopla, De la Entrada al Templo II, P.G. 98, col. 296.

55 Germano de Constantinopla, De la Entrada al Templo II, P.G. 98, col. 293 C:

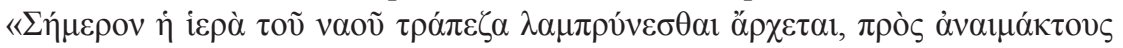

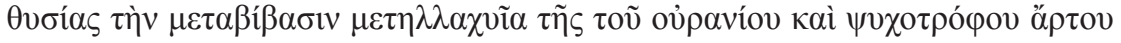

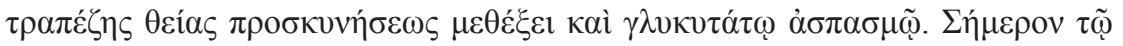

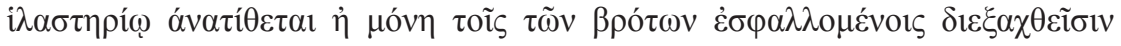

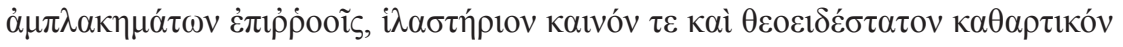

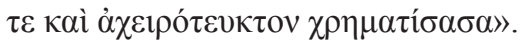

56 Germano de Constantinopla, De la Entrada al Templo II, P.G. 98, cols. 305308 . 
una roca "que fue cortada no con mano, que aplastó altares idólatras y se convirtió en la cabeza del rincón que era maravilloso a nuestros ojos" ${ }^{57}$. Los antiguos lugares del culto, que aquí se podían referir al Templo de Salomón en el que María fue criada o en los templos paganos, fueron reemplazados por la nueva iglesia que fue fundada en Cristo, la piedra angular o "la roca cortada sin manos" $" 58$.

\section{Conclusiones}

Veamos ahora recapitular en este punto algunos de los problemas que se han elevado por encima y tratar de sacar algunas conclusiones. En primer lugar, está claro que el Protoevangelio ocupa un lugar prominente en las Homilías del período bizantino medio, a partir del siglo VIII en adelante, ya que el propio texto apócrifo inspiró las fiestas marianas. Después de los siglos en los que el Protoevangelio era ampliamente conocido pero rara vez citado explícitamente por los Padres de la Iglesia, los predicadores y los himnógrafos parecen haberlo aceptado plenamente como parte de la tradición santa, es aceptado como un texto sagrado de la tradición canónica. El uso del texto va desde la exégesis narrativa, con desarrollo dramático de la historia que contiene, hasta diversas formas de interpretación teológica y simbólica. En este trabajo hemos tratado de limitar nuestro análisis a Homilías sobre la Concepción, la Natividad y la Entrada de la Virgen María; el efecto del Protoevangelio también se relaciona con otras fiestas como la Anunciación (a la que el texto apócrifo agrega detalles tales como la visita de la Virgen en el pozo, y la hilatura de hilos para la cortina del templo justo antes de que el Arcángel Gabriel se acerque) y la Natividad de Cristo (que ocurrió en una cueva y fue atendida por la partera Salomé).

Se sabe que el Protoevangelio de Santiago influyó la himnografía y el arte bizantinos posteriores ${ }^{59}$. Lo que todavía no se entiende es cuando

57 Germano de Constantinopla, De la Entrada al Templo II, P.G. 98, col. 308A:

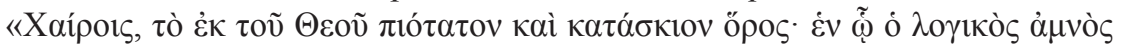

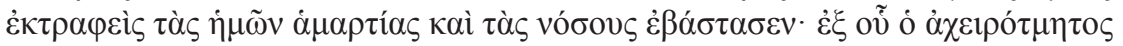

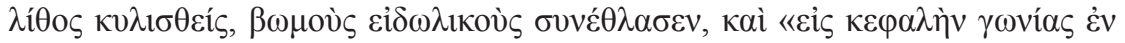

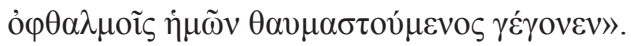

58 Cf. Efes. 2,20. Dan. 2.34.

59 Véase indicativamente X. Jacob, La vie de Marie interpretée par les artistes des églises rupestres de Cappadoce, en Cahiers de l'art medieval 6.1. (1971- 
y por qué el texto comenzó a ser adoptado la tradición litúrgica corriente ${ }^{60}$. Sugerimos antes que los autores de textos litúrgicos, empezando por Romanos el Melodista, se volvían a los textos de la tradición apócrifa cuando trataban de honrar las fiestas marianas, que sin embargo no tenían fundamento en las Escrituras. Otra posible explicación podría ser que el interés en los textos apócrifos, como el Protoevangelio, fue motivado por el creciente respeto hacia la Virgen María, como una imagen santa por su propio derecho ${ }^{61}$. El establecimiento de fiestas en la memoria de María ha ocurrido como resultado del culto creciente, más que como una causa de creciente interés por las fuentes textuales.

También debemos preguntarnos si Romanos el Melodista con su kontakion sobre la Virgen María actuó como catalizador de este desarrollo, afectando así a los predicadores y himnógrafos posteriores ${ }^{62}$. No cabe duda de que, tras el temprano énfasis cristológico del siglo V sobre los sermones marianos y los himnos a la Virgen, un renovado interés por las cualidades personales y la historia, las emociones y el poder de intercesión surgió durante el siglo VI. Por último, si bien hemos observado el creciente énfasis de la Virgen María y el uso litúrgico del Protoevangelio y otros textos apócrifos a partir del siglo VI, es importante reconocer que lo

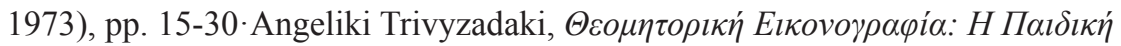

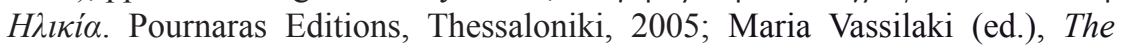
Mother of God: Representations of the Virgin in Byzantine Art, Milan, 2000.

60 Una hipótesis interesante que Niki Tsironis hace es que las cuestiones particulares, como las propiedades de los padres de la Virgen, primero se introdujeron en la poesía, luego en la Homilética, más tarde en la iconografía y finalmente en la liturgia. Véase N. Tsironis, "From poetry to liturgy: the cult of the virgin in the Middle Byzantine period" en M. Vassilaki (ed.), Images of the Mother of God. Perceptions of the Theotokos in Byzantion, Aldershot, Ashgate, 2005, pp. 91-99.

61 Averil Cameron, "Images of authority: élites and icons in late sixth-century Byzantium", Past \& Present 84, 1 (1979), pp. 3-35· eadem, "The Theotokos in sixth-century Constantinople. A city finds its symbol”, JTS 29(1978), pp. 79108 .

62 Sobre este tema, véase J. Grosdidier de Matons, Romanos le Mélode et les origins de la poésie religieuse à Byzance, Paris, 1977, pp. 48-65; M.B. Cunningham, The reception of Romanos in Middle Byzantine homiletics and hymnography", DOP 62 (2008), pp. 251-260. 
anterior continuó siendo interpretado a la luz de la doctrina cristológica ya que se expresó durante el siglo V. Los sermones e himnos festales continuaron durante todo el período bizantino, enfatizando, a través del argumento, la imagen y la tipología, el papel esencial de la Virgen María para la Encarnación de Cristo.

\section{REFERENCIAS BIBLIOGRÁFICAS}

AUBINAU, M. (1978). Les homélies festales d'Hésychius de Jérusalem. Bruselas: vol. 1 (Subsidia Hagiographica 59).

BAKER, M. (2006). Justinian's 'New Church' and the Entry of the Mother of God into the Temple, Sourozh 103, 15-33.

BORRET, M. (1967). Origène. Contre Celse. París (SC 132).

BOULLUEC, Allan de. (1997). Les Stromates. Stromate VII. París (SC 248).

BRAKKE, D. (1995). Athanasius and Asceticism. Baltimore and London: John Hopkins University Press.

BRUSSON L.- M.-H. Congourdeau- J.L. Solère. (2008). L'embryon: formation et animation. Antiquité grecque et latine. Traditions hébraique, chrétienne et islamique (Histoire des doctrines de l'antiquité classique 38). París: Librairie Philosophique J. Vrin

CAMERON, Averil. (1979). "Images of authority: élites and icons in late sixthcentury Byzantium", Past \& Present 84/1, 3-35.

CONSTAS, N. (Padre Máximo). (2003). Proclus of Constantinople and the Cult of the Virgin in Late Antiquity. Leiden: Brill.

CUNNINGHAM, M. (2004). "The Meeting of the Old and the New: The Typology of Mary the Theotokos in Byzantine Homilies and Hymns" en R.N. Swanson (ed.), The Church and Mary (Studies in Church History 39), Boydell \& Brewer, 2004, 52-62.

CUNNINGHAM, M.B. (2008). The reception of Romanos in Middle Byzantine homiletics and hymnography", DOP 62, 251-260.

DALEY, Brian J. (1998). On the Dormition of Mary. Early Patristic Homilies. Crestwood NY.

DE STRYCKER, E. (1961). La forme la plus ancienne du Protévangile de Jacques Bruselas: Subsidia Hagiographica 33.

DÖLGER, F. (1950). "Iohannes von Euboia", AnalBoll 68, 5-26.

EADEM. (1978). "The Theotokos in sixth-century Constnantinople. A city finds its symbol”, JTS 29, 79-108CARO, R. (1971-1973). La homilética mariana en el siglo V. 3 vols. Dayton (Marian Library Studies 3) 
--------, (2011). "The use of the Protoevangelion of James in 8th-century homilies on the Mother of God" en L. Brubaker and M. Cunningham (eds.), The Cult of the Mother of God in Byzantium. Texts and Images. Farnham: Ashgate, 165-178.

--------, Leena Mari- Külzer Andreas, Allen Pauline. (2015). PRESBEIA THEOTOKOU. The Intercessory Role of Mary across Times and Places in Byzantium (4th-9th Century). Viena: Academia Austríaca de Ciencias. Veröffentlichungen zur Byzanzforschung, Volume 39.

-------, (2011). "Emotion and the senses in Marian homilies of the Middle Byzantine period" en L. Brubaker \& M. B. Cunningham, The Cult of the Mother of God. Texts and Images. Farnham: Ashgate 179-196.

ELLIOTT, J.K. (1993). The Apocryphal New Testament. A Collection of Apocryphal Christian Literature in an English Translation Based on M.R. James. Oxford.

GROSDIDIER DE MATONS, J. (1977). Romanos le Mélode et les origins de la poésie religieuse à Byzance. Paris.

HALKIN, F. (1966). "La passion de Ste Parascève par Jean d'Eubée" en P. Wirth (ed.), Polychronion. Festschrift für Franz Dölger. Heidelberg: 231-237.

IDEM, J.K. (2008). "Mary in the apocryphal New Testament" en C. Maunder (ed.), The Origins of the Cult of the Virgin Mary. London \& New York: Bloomsbury Academic, 50-60.

-------, (1980-1981). "Liturgie et hymnographie: kontakion et canon", DOP 24/25, 31-43.

IDEM. (2011). "John of Damascus on the Mother of God as a link between humanity and God", en L. Brubaker and M. Cunningham (eds.), The Cult of the Mother of God, Texts and Images. Farnham: Ashgate, 153-161

JACOB, X. (1971-1973). "La vie de Marie interpretée par les artistes des églises rupestres de Cappadoce", en Cahiers de l'art medieval 6.1., 15-30.

KLOSTERMANN, E. - BENZ, E. (1935). Die Griechischen Christlichen Schriftsteller. Leipzig.

KOTTER, B. (1969-1988). Die Schriften Des Johannes von Damaskos (Patristische Texte und Studien 7, 12, 17, 22, 29). Berlin-New York: Walter de Gruyter.

LAFONTAINE-DOSOGNE, J. (1975). "Iconography of the cycle of the life of the Virgin", en P. Underwood (ed.), The Kariye Djami. Studies in the Art of the Kariye Djami and its Intellectual Background. v. 4. London.

LOUTH, A. (2002). St. John Damascene. Tradition and Originality in Byzantine Theology. Oxford.

MAAS, P. -C.A. Trypanis. (1963). Sacti Romani Melodi Carmina Cantica. Cantica Genuina. Oxford.

MATEOS, J. (1962). Le Typicon de la Grande Église: Ms. Sainte-Croix no. 40 Xe siècle (2 vols.). Roma. 
PELTOMAA, L.M. (2001). The Image of the Virgin Mary in the Akathistos Hymn. Leiden: Brill.

SHOEMAKER, S. (2002). Ancient Traditions of the Virgin Mary's Dormition and Assumption. Oxford: OUP.

STÄHLIN, O. (1906). Die Griechischen Christlichen Schriftsteller 52 (17)/2. Leipzig.

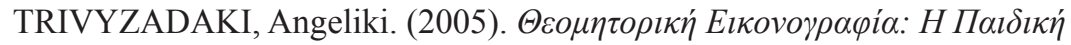

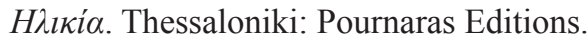

TSIRONIS, N. (2005). "From poetry to liturgy: the cult of the virgin in the Middle Byzantine period" en M. Vassilaki (ed.), Images of the Mother of God. Perceptions of the Theotokos in Byzantion. Aldershot: Ashgate, 91-99.

VAILHE, S. (1901-1902). La féte de la presentation de Marie au temple, EO 5, 212-218.

VASSILAKI, Maria (2000). The Mother of God: Representations of the Virgin in Byzantine Art. Milan.

VOULET, P. (1961). S. Jean Damascène, Homélies sur la nativité de la dormition (Sources Chrétiennes 80). Paris: Editions du Cerf.

WENGER, A. (1955). L'Assomption de la très sainte Vierge dans la tradition Byzantine du Vie aux Xe siècle (Archives de l'Orient Chretien 5). Paris. 